DOI : https://doi.org/ 10.24123/jbt.v5i1.4079

\title{
THE EFFECT OF TAX MINIMIZATION, BONUS MECHANISM, FOREIGN OWNERSHIP, EXCHANGE RATE, AUDIT QUALITY ON TRANSFER PRICING DECISIONS
}

\author{
Marfuah $^{1}$, Sanintya Mayantya ${ }^{2}$, Priyono Puji Prasetyo ${ }^{3}$ \\ ${ }^{1}$ Universitas Islam Indonesia; 081578700383, ${ }^{2}$ Universitas Islam Indonesia; \\ 081325108079, ${ }^{3}$ Universitas Ahmad Dahlan; 082133216216 \\ Email:marfuah@uii.ac.id ${ }^{1}, 14312189 @$ alumni.uii.ac.id ${ }^{2}$, \\ priyono.prasetyo@pbs.uad.ac.id ${ }^{3}$
}

\begin{abstract}
The purpose of this study was to determine the effect of tax minimization, bonus mechanisms, foreign ownership, exchange rates, and audit quality on transfer pricing in manufacturing companies in Indonesia. The population of this research was all manufacturing companies listed on the Indonesia Stock Exchange from 2017 to 2019. By using the purposive sampling method, 81 companies were selected as the research sample. Based on logistic regression analysis, it was proven that the tax minimization variable has a significant positive effect on transfer pricing decisions. Likewise, the audit quality variable is proven to have a significant negative effect on transfer pricing decisions in manufacturing companies in Indonesia. Meanwhile, the bonus mechanism, foreign ownership, and exchange rate variables were not proven to have a significant effect on the company's transfer pricing decision. These results indicated that the greater the tax minimization carried out by the company and the lower the audit quality will increase the probability of the company in conducting transfer pricing, and vice versa. The results of this study have implications for encouraging the government to make regulations that can prevent transfer pricing practices between companies that have a special relationship that might harm the government from tax revenue.
\end{abstract}

Keywords: bonus mechanism; foreign ownership; tax minimization; transfer pricing

\section{Introduction}

The development of the business world at this time encourages the growth of multinational companies whose scope of operations is not only in their own country, but also reaching abroad. One of the problems faced by multinational companies is the difference in tax rates between countries. This tax rate difference makes multinational companies do transfer pricing in international transactions (Nurjanah, et al., 2015: 5). Transfer pricing is often used as a corporate strategy to get high profits from sales. Forprofit companies will try to get the maximum profit through various means including through cost efficiency. This can be done by doing transfer pricing (Hartati, et al., 2015: 6). Transfer pricing is the transfer price of the selling price of goods, services, and intangible assets to subsidiaries or to related parties or have special relationships located in various countries. Transfer pricing transactions can occur in divisions within one 
company, between local companies, or local companies with companies that are abroad (Hartati, et al., 2015: 6).

The phenomenon related to the practice of transfer pricing carried out by multinational companies was successfully dismantled by the Directorate General of Taxes in 2017. The Directorate General of Taxes succeeded in dismantling the motives of 2,000 multinational or foreign companies that were identified as taxing. On average, these multinational companies are in arrears of Corporate Income Tax (Article 25 and 29). According to Mekar Satria Utama as Director of Public Relations Services and Counseling from the Directorate General of Taxes, on average 2,000 foreign companies use transfer pricing mode. The goal, first, is to outsmart the amount of profit so that tax payments and dividend payments become low. Second, inflating profits to polish (window-dressing) financial statements. From this practice the state lost trillions of rupiah due to the practice of transfer pricing of foreign companies in Indonesia. The second mode is that these foreign companies usually make use of fiscal facilities, such as tax allowance to avoid tax payments after the tax allowance period runs out (Sari, 2016). In general transactions between taxpayers who have a special relationship are done through transfer pricing. The practice of transfer pricing between parties that have a special relationship can result in a transfer of income, a tax base or the cost of one taxpayer to other taxpayers who can be engineered to reduce the total amount of tax owed on taxpayers who have that special relationship.

The Indonesian government began regulating the practice of transfer pricing in 1993 through SE-04 / PJ.7 / 1993. Then followed by KMK 650 / KMK.04 /1994 about the list of tax haven countries. Only after that in 2009 did Indonesia more seriously pay attention to the practice of transfer pricing through Law Number 36 of 2008 concerning Income Taxes (Setiawan, 2014). Research on the factors that allegedly drove the practice of transfer pricing in Indonesia has been conducted by several researchers, but gave inconsistent results. Refgia research results (2017: 553), Mayowan, \& Karjo (2016:7), Hartati et al. (2015: 12), and Nurjanah et al. (2015:11) shows that tax minimization has a significant effect on transfer pricing, while the results of Mispiyanti (2015:72) research show that tax minimization has no significant effect on transfer pricing.

Research Hartati et al. (2015: 15) and Nurjanah et al. (2015:11) found that the bonus mechanism had a significant effect on transfer pricing, while the research by Saraswati et al. (2017:1022), Refgia (2017: 553), Rosa et al. (2017: 12) and Mispiyanti (2015: 72) found no effect of the bonus mechanism on transfer pricing. Refgia (2017: 553) found that foreign ownership had a significant positive effect on transfer pricing, while Tiwa et al. (2017:2673) and Nurjanah et al. (2015:12) failed to prove the positive influence of foreign ownership on transfer pricing. Chan, Landry, \& Jalbert, (2004: 40) found that the exchange rate had a significant positive effect on transfer pricing while Marfuah \& Azizah (2014:164) failed to prove that the exchange rate had an effect on transfer pricing. Nurjanah et al. (2015: 12) found the influence of company size on transfer pricing while Refgia's research (2017:554) showed that company size had no effect on transfer pricing. Rosa et al (2017:11) research results show that audit quality has a positive influence on transfer pricing, while the results of Mayowan \& Karjo (2016:7) research indicate that audit quality does not significantly influence transfer pricing.

This study attempts to re-examine the determinants of transfer pricing variables that have not shown consistent results. Therefore the purpose of this study is to examine the effect of tax minimization, bonus mechanisms, foreign ownership, exchange rates, and audit quality on transfer pricing decisions in manufacturing companies in Indonesia. The main reason this research was conducted is because there are still several previous studies 
that found varied results related to the effect of tax minimization variables, bonus mechanisms, foreign ownership, exchange rates, and audit quality on transfer pricing decisions.

\section{Literature Review International Aspects of Transfer Prices}

According to Datar and Rajan (2018:882), what is meant by transfer pricing is the price charged by one subunit for a product or service that is supplied to another subunit in the same organization. According to Suandy (2011: 44), transfer pricing is a systematic manipulation of price with the intention of reducing artificial profit, making it appear as if the company has a loss, avoiding taxes or duties in a country. So, from some of the above it can be concluded that what is meant by transfer pricing is the price contained in each product or service from one division to another in the same company, or between companies that have a special relationship. Transfer pricing transactions can occur in divisions within one company, between local companies, or local companies with companies that are abroad.

Based on the parties involved, transfer pricing transactions can be grouped into two types, namely (1) Intercompany transfer pricing is a transaction that occurs between two companies that have a special relationship, (2) Intracompany transfer pricing is a transaction that occurs between divisions within a company. Transfer pricing can be done at a company in a country (domestic transfer pricing), or with different countries (international transfer pricing). The purpose of the transfer price changes if it involves a multinational corporation (MNC) as well as goods that are transferred across national borders. The objective of determining international transfer prices is focused on minimizing taxes, duties, and foreign exchange risk, together with increasing a company's competitiveness and improving relations with foreign governments. Although domestic goals such as managerial motivation and division autonomy are always important, they often become secondary when international transfers are involved. Companies will focus more on reducing total taxes or strengthening foreign subsidiaries. Therefore transfer pricing is also often associated with a systematic pricing engineering aimed at reducing profits which in turn reduces the amount of taxes or duties from a country.

\section{Effects of Tax Minimization on Transfer Pricing}

Hartati et al. (2015: 8) and Gusnardi (2009:39), stated that multinational companies do transfer pricing to minimize corporate tax obligations globally. Tax motivation in transfer pricing in multinational companies is carried out by moving income to the country with the lowest tax burden, where the country has a group of companies or divisions of companies that operate.

Yuniasih et al. (2012:14), states that tax has a positive effect on the company's decision to transfer pricing. The tax burden that is increasingly large triggers companies to do transfer pricing in the hope that they can reduce the burden. Because in business practices, entrepreneurs generally identify tax payments as an expense so that they will always try to minimize these costs in order to optimize profits. Increasing tax burden triggers companies to do transfer pricing in the hope that they can reduce the burden, because in business practices, entrepreneurs generally identify tax payments as an expense so that they will always try to minimize these costs in order to optimize profits (Hartati et al., 2015: 12). The effect of tax minimization on transfer pricing is also evidenced in the research of Saraswati et al. (2017:1024) and Tiwa et al. (2017: 2673) who found that tax had a significant positive effect on the application of transfer pricing. 


\section{H1: Tax minimization has a positive effect on transfer pricing Effect of Bonus Mechanisms on Transfer Pricing}

Bonus mechanisms are additional compensation or rewards given to employees for the successful achievement of goals targeted by the company. A bonus mechanism based on earnings is the most frequently used method by companies in giving awards to directors or managers (Refgia, 2017: 553). According to Saraswati et al. (2017:1024), company owners usually use a bonus system to improve employee performance, so that the profits generated each year are higher. Some companies use a bonus plan. In positive accounting theory there is a bonus plan hypothesis stating that company managers basically want a large bonus from the company, one way to change reported earnings. To maximize current period earnings, the manager must adjust to the accounting procedures applied if there is a plan for giving bonuses by the owner. If the bonus received by the manager is based on the achievement of the company's overall profit then it is logical if the manager reports high net income.

Referring to the study of Lo et al., (2010:1), which found that there is a tendency for management to use transfer pricing transactions to maximize the bonuses they receive if the bonus is based on profit. So it can be concluded that managers will tend to take actions that regulate net income by means of transfer pricing practices in order to maximize the bonuses they receive. Therefore, the higher the company's profit to be achieved to maximize bonuses, the more likely the transfer pricing practice is carried out by the company's management (Hartati et al., 2015: 15). Hartati et al. (2015: 15) and Nurjanah et al. (2015: 11) shows that the bonus mechanism has a significant positive effect on transfer pricing.

\section{H2: The bonus mechanism has a positive effect on transfer pricing Effects of Foreign Ownership on Transfer Pricing}

In the ownership structure there are two types of shareholders, namely controlling shareholders and non-controlling shareholders. The controlling shareholder has the authority to oversee management, because the controlling shareholder has a higher position and has better access to information. This allows the controlling shareholder to abuse the control rights for his own welfare. Companies whose shares are owned by foreign parties allow companies to conduct transactions between related parties. If a foreign party has a majority share, the foreign party will have the power to control the management in transfer pricing.

Research conducted by Dyanty et al. (2011:20) shows that the higher control rights held by controlling shareholders, including foreign controlling shareholders, allow controlling shareholders to order management to conduct related party transactions that are detrimental to non controlling shareholders and benefit themselves. One possible related party transaction is transfer pricing.

Kiswanto and Purwaningsih (2013: 12) show that the increasing percentage of foreign ownership can put shareholders in a strong position to control the company, including controlling the decisions regarding the transfer pricing done by the company so that foreign ownership influences transfer pricing. The influence of foreign ownership on transfer pricing is supported in research Refgia (2017:553) and Kiswanto \& Purwaningsih, (2013: 12) which show that foreign ownership has a positive effect on transfer pricing. 


\section{H3: Foreign ownership has a positive effect on transfer pricing Effects of Exchange Rate on Transfer Pricing}

An exchange rate or often referred to as an exchange rate is the price of one unit of foreign currency in the domestic currency or it can also be said the price of the domestic currency against foreign currencies. Exchange rates have two accounting effects, namely to enter foreign currency transactions and disclosure of profits and / or losses that can affect the company's overall profit. As a result, multinational companies may try to reduce foreign exchange risk by moving funds to strong currencies through transfer pricing to maximize overall corporate profits (Chan et al., 2004: 23). The results of Chan et al. (2004:23) shows that the exchange rate has a significant positive effect on transfer pricing. Based on the description above, the hypothesis proposed is:

\section{H4: Exchange rate has a positive effect on transfer pricing Effects of Audit Quality on Transfer Pricing}

Audit quality can be interpreted as good or not an examination conducted by the auditor (Mayowan \& Karjo, 2016:7). Transparency is an important principle in GCG. This can be done by reporting matters related to taxation in the capital market and RUPS. Audit quality is based on considerations which include several elements that are in Good Corporate Governance, namely, openness, honesty and accountability (Rosa et al., 2017: 12).

Annisa and Kurniasih (2012:133) stated that audit quality affects the implementation of tax avoidance. The more audit quality of a company, the company tends not to manipulate earnings for tax purposes. One way in tax avoidance is transfer pricing. If a company is audited by a qualified Public Accounting Firm, it will be increasingly difficult to implement an aggressive tax policy. The more quality audit results of a company, the company tends to be more transparent in reporting matters regarding tax so that the transfer pricing practice within the company will be smaller. The results of Mayowan \& Karjo's research (2016:7) show that audit quality has a significant effect on transfer pricing.

\section{H5: Audit quality has a negative effect on transfer pricing. Frame Work of Research}

A frame work of research for describing the relationship between the independent variables and the dependent variable is presented in Figure 1 below: 


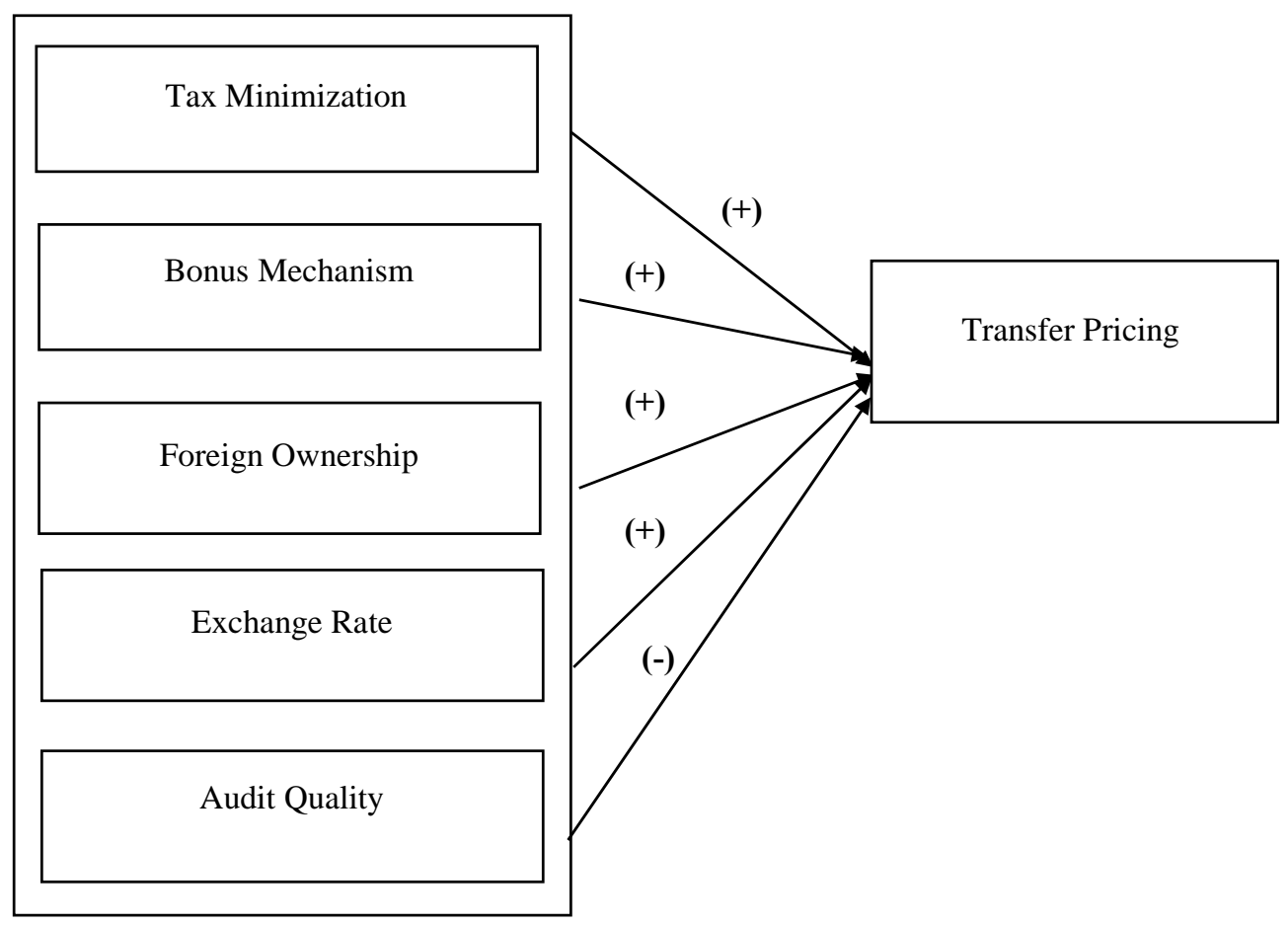

Picture 1

Research Model

\section{Research Method Population dan Sample}

The population in this study are manufacturing companies listed on the Indonesia Stock Exchange (IDX) in 2017-2019, as many as 27 companies were selected as samples or 81 companies for 3 years. The sample selection process is presented in table 1 below:

Table 1

The Sample Selection Process

\begin{tabular}{|l|l|l|}
\hline NO & Criteria & Total \\
\hline 1. & $\begin{array}{l}\text { Manufacturing companies listed on the Indonesia Stock Exchange in 2017- } \\
2019\end{array}$ & 142 \\
\hline 2. & $\begin{array}{l}\text { Companies that do not report the company's financial statements in a row } \\
\text { in 2017-2019 }\end{array}$ & $(28)$ \\
\hline 3. & Companies that do not issue financial statements in rupiah & $(23)$ \\
\hline 4. & Companies that report losses in 2017-2019 & $(17)$ \\
\hline 5. & $\begin{array}{l}\text { Foreign-controlled company with ownership percentage below 20\% } \\
\text { Number of samples for 1 year }\end{array}$ & $(47)$ \\
\hline Number of samples for 1 year & 27 \\
\hline \multicolumn{2}{|l|}{ Number of samples for 3 year } & 81 \\
\hline
\end{tabular}

Source: secondary data, 2021

\section{Data collection technique}

The data used in this study are secondary data in the form of company annual reports. Data sources were obtained from the website www.idx.co.id. Data is collected by 
the documentation method, namely by studying or studying documents or written sources and other archives that are relevant to the research topic.

\section{Research Variables}

The variables of this study consisted of independent and dependent variables. Tax minimization, bonus mechanism, foreign ownership, exchange rate and audit quality are independent variables while transfer pricing is the dependent variable in this study. Transfer pricing variables are calculated using the dichotomous approach, namely by looking at the existence of sales to parties that have a special relationship. For companies that sell to parties that have a special relationship are given a value of 1 and those not given a value of 0 .

Tax minimization variable is measured using a ratio scale. The ratio used is the Effective tax rate (ETR). Effective tax rate is the ratio of tax expense minus differed tax expense divided by taxable profit. The bonus mechanism variable is measured using a ratio scale that is the Net Profit Trend Index (ITRENDLB). The variable of foreign ownership is measured using a ratio scale that is the number of share ownership by foreign parties divided by the number of shares outstanding. Variable exchange rate is measured using a ratio scale that is the profit and loss of the exchange rate divided by the income before tax.

Audit quality variables are measured using dummy variables. If the financial statements are audited by a Public Accounting Firm affiliated with The Big Four Auditors, they are given a score of 1 , conversely, if the financial statements are audited by a public accounting firm that is not affiliated with The Big Four Auditors, they will be given a score of 0 . As for the 4 (four) affiliated public accounting firms with The Big Four Auditors are (1) the Public Accounting Firm- Purwantono, Sarwoko, Sandjaja affiliated with Ernst \& Young, (2) the Public Accounting Firm- Osman Bing Satrio and Partners affiliated with Deloitte Touche Tohmatsu, (3) the Public Accounting FirmSiddharta and Widjaja affiliated with KPMG, and (4) the Public Accounting FirmTanudireja Wibisana \& Partners is affiliated with PricewaterhouseCoopers.

\section{Data Analysis Technique}

Data analysis method used to test the hypothesis in this study is logistic regression analysis. The logistic regression equation model is as follows:

$\operatorname{Logit}(\pi j)=\operatorname{Ln} \frac{\pi}{1-\pi}=\beta 0+\beta 1 X 1+\beta 2 X 2+\beta 3 X 3+\beta 4 X 4+\beta 5 X 5+e \ldots(1)$

\section{Explanation:}

$\pi \mathrm{j}$ : probability that the $\mathrm{j}$ factor or covariate has a response $=1$ from the binary logistic regression response that has a value of $0 \beta 0$ : constants, $\beta 1, \beta 2, \beta 3, \beta 4 \beta 5$ : coefficient of the independent variable, X1: Tax Minimization, X2: Bonus Mechanism, X3: Foreign Ownership, X4: Exchange Rate, X5: Audit Quality, e: error term

Logistic regression analysis was used to examine the effect of tax minimization variables, bonus mechanism, foreign ownership, exchange rate, and audit quality on transfer pricing. Logistic regression analysis was used because transfer pricing which is the independent variable in this study is a dummy variable. Logistic regression analysis includes the feasibility test of the regression model, the overall model fit test, the coefficient of determination test, and the Wald's significance test. 


\section{Res ults and Discussion \\ Descriptive Analysis}

Descriptive statistical analysis in this study illustrates the data of each research variable which includes the mean, minimum, maximum, and standard deviation. Statistical descriptive results are presented in table 2 below:

Table 2

Descriptive Statistics

\begin{tabular}{|l|c|c|c|c|}
\hline & Minimum & Maximum & Mean & $\begin{array}{c}\text { Standar } \\
\text { Deviation }\end{array}$ \\
\hline Tax Minimization (X1) & -26.668 & 7.983 & -0.336 & 4.190 \\
\hline Bonus Mechanism (X2) & -0.500 & 9.294 & 1.307 & 1.295 \\
\hline Foreign Ownership (X3) & 0.225 & 0.982 & 0.605 & 0.235 \\
\hline Exchange Rate (X4) & -0.687 & 0.606 & -0.008 & 0.152 \\
\hline Audit Quality (X5) & 0 & 1 & 0.770 & 0.391 \\
\hline Trasnfer Pricing (Y) & 0 & 1 & 0.850 & 0.357 \\
\hline
\end{tabular}

Source: Results of data processing with SPSS 22.0 software, 2021

The variable of transfer pricing (Y) has an average value of 0.850.This shows that the sample companies listed on the IDX in 2017-2019 performed transfer pricing on an average of $85 \%$ or as many as 69 companies while the remaining $15 \%$ or 12 companies did not carry out transfer pricing.

The variable of tax minimization (X1) has an average value of -0.336 , with a minimum and maximum value of -26.668 and 7.983 , respectively. This shows that the average tax burden on manufacturing companies listed on the IDX in 2017-2019 is 33.6\% of profit before tax. The company with the lowest ETR of -26,668 was PT Wismilak Inti Makmur Tbk in 2018 and the largest of 7,982 was PT Nusantara Inti Corpora Tbk in 2017.

The variable bonus mechanism (X2) has an average value of 1.307, with minimum and maximum values of -0.5000 and 9.294 , respectively. This shows that the average bonus mechanism of the sample companies is $130.7 \%$, which means that the percentage of net profit achievement in the current year against the previous year is $30.7 \%$. The company with the lowest net profit trend index of -0.500 was PT Tirta Mahakam Resources Tbk in 2017 and the highest of 9,294 was PT Sekar Laut Tbk in 2019.

The variable of foreign ownership (X3) has an average value of 0.604 , with a minimum and maximum value of 0.225 and 0.982 , respectively. The company with the lowest foreign ownership of 0.225 was PT Wismilak Inti Makmur Tbk in 2017-2019 and the highest was 0.982 was PT Hanjaya Mandala Sampoerna Tbk in 2019.

The variable of exchange rate (X4) has an average value of -0.007586 , with a minimum and maximum value of -0.6866 and 0.6056 , respectively. The company with the lowest exchange rate of -0.6866 was PT JPFA Comfeed Indonesia Tbk in 2018 and the highest was 0.6056 was PT Nusantara Inti Corpora Tbk in 2018.

The variable of audit quality (X5) has an average value of 0.77 . This shows that the sample companies listed on the IDX in 2017-2019 were audited by Public Accounting Firm-The Big Four on average of $77 \%$ or 62 companies while the remaining 23\% or 19 companies were not audited by Public Accounting Firm-The Big Four. 


\section{Assumption Test}

The assumption test used in the logistic regression analysis is the multicollinearity test. Multicollinearity test in logistic regression uses correlation between independent variables. The logistic regression model does not occur multicollinearity if the value of the correlation coefficient between the independent variables is not greater than 0.8 . The results of the multicollinearity test with the correlation matrix are presented in table 3 .

Table 3

Multicollinearity Test Results

\begin{tabular}{|c|c|c|c|c|c|}
\hline Variable & $\begin{array}{c}\text { Tax } \\
\text { Minimiza } \\
\text { tion }\end{array}$ & $\begin{array}{c}\text { Bonus } \\
\text { Mecanis } \\
\mathbf{m}\end{array}$ & $\begin{array}{c}\text { Foreign } \\
\text { Ownership }\end{array}$ & $\begin{array}{c}\text { Exchange } \\
\text { Rate }\end{array}$ & $\begin{array}{c}\text { Audit } \\
\text { Qualit } \\
\mathbf{y}\end{array}$ \\
\hline $\begin{array}{c}\text { Tax } \\
\text { Minimization }\end{array}$ & 1000 & 0.104 & -0.395 & -0.323 & 0.427 \\
\hline $\begin{array}{c}\text { Bonus } \\
\text { Mecanism }\end{array}$ & 0.104 & 1000 & -0.061 & -0.432 & 0.280 \\
\hline $\begin{array}{c}\text { Foreign } \\
\text { Ownership }\end{array}$ & -0.395 & -0.061 & 1000 & 0.142 & -0.316 \\
\hline Audit Quality & 0.427 & 0.280 & -0.316 & -0.260 & 1000 \\
\hline Exchange Rate & -0.323 & -0.432 & 0.142 & 1.000 & -0.260 \\
\hline
\end{tabular}

Source: Results of data processing with SPSS 22.0 software, 2021

Based on Table 3, it can be seen that the correlation coefficient value between independent variables is not greater than 0.8. This shows that there is no symptom of multicollinearity between the independent variables.

\section{Regression Model Feasibility Test}

The feasibility of the regression model was assessed using Hosmer and Lemeshow's Goodness of Fit Test. If the significance value in Hosmer and Lemeshow's Goodness of Fit Test is greater than 0.05 then the model used is able to predict the value of the observation. The results of the feasibility test of the regression model in this study are presented in Table 4.

Table 4

Regression Model Feasibility Test

\begin{tabular}{|c|c|c|c|}
\hline Step & Chi-Square & Df & Sig. \\
\hline 1 & 5.641 & 8 & 0.687 \\
\hline
\end{tabular}

Source: Results of data processing with SPSS 22.0 software, 2021

Based on Table 4.8 the results of the regression model feasibility test, it can be seen that the Chi-Square value is 5,641 with a significance of 0.687 . This shows that the significance value is greater than 0.05 so it can be concluded that the model used is able to predict the value of the observations.

\section{Overall Model Fit Test}

The overall model fit test is used to see whether the hypothesized model fits the data, both before and after the independent variables are included in the model. To see the suitability of the overall regression model, it is done by comparing the value of $-2 \log$ 
likelihood (-2LL) at the beginning (Block Number $=0)$ with a value of $-2 \log$ likelihood $(-2 \mathrm{LL})$ at the end (Block Number $=1)$. The value of $-2 \log$ likelihood $(-2 \mathrm{LL})$ at the beginning (Block Number $=0$ ) which experienced a decrease in the value of $-2 \mathrm{log}$ likelihood (-2LL) at the end (Block Number $=1$ ) after the inclusion of several independent variables in this study showed that the hypothesized model fit with the data. The results of the overall suitability test of the regression model in this study can be seen in Table 5.

Table 5

Overall Model Fit Test

\begin{tabular}{|c|c|}
\hline Keterangan & $\mathbf{- 2}$ Log Likelihood \\
\hline Block Number $=\mathbf{0}$ & 67.956 \\
\hline Block Number $=\mathbf{1}$ & 48.619 \\
\hline
\end{tabular}

Source: Results of data processing with SPSS 22.0 software, 2021

Based on Table 5, the results of the overall suitability test of the regression model, it can be seen that the value of $-2 \log$ likelihood (-2LL) at the beginning (Block Number $=$ 0 ) decreased in the value of $-2 \log$ likelihood (-2LL) at the end (Block Number $=1)$ after the entry several independent variables in this study. It can be seen that the value of $-2 \log$ likelihood (-2LL) at the beginning (Block Number $=0$ ) is 67.956 . While the value of -2 $\log$ likelihood (-2LL) at the end (Block Number $=1$ ) decreased after the inclusion of several independent variables in this study, the value of -2LL became 48,619. This decrease indicates a good regression model or in other words the hypothesized model fits the data, meaning that the addition of independent variables, namely tax minimization, bonus mechanism, foreign ownership, exchange rate, and audit quality will improve the fit model in this study.

\section{Coefficient of Determination Test}

The coefficient of determination is carried out to find out how much the variability of the dependent variable can be explained by the independent variable. The coefficient of determination can be seen in the value of Nagelkerke R Square. The Nagelkerke R Square value of 0.374 means that the variability of the dependent variable can be explained by the independent variable by $37.4 \%$, while the remaining $62.6 \%$ is explained by other variables outside the research model. The results of the coefficient of determination in this study can be seen in Table 6 .

Tabel 6

Coefficient of Determination Test

\begin{tabular}{|c|c|c|c|}
\hline Step & -2 Log Likelihood & $\begin{array}{c}\text { Cox \& Snell R } \\
\text { Square }\end{array}$ & $\begin{array}{c}\text { Nagelkerke R } \\
\text { Square }\end{array}$ \\
\hline 1 & $48.619^{\mathrm{a}}$ & 0.212 & 0.374 \\
\hline
\end{tabular}

Source: Results of data processing with SPSS 22.0 software, 2021

\section{Hypothesis Test Results}

The Sig-Wald test is used to determine whether the independent variable affects the dependent variable. Hypothesis testing in this study is Ho is rejected if the significance value is $<0.05$ and each regression coefficient is in the direction predicted. The results of hypothesis testing in this study can be seen in Table 7. 
Table 7

Hypothesis Test Results

\begin{tabular}{|l|c|l|l|l|l|l|}
\hline \multicolumn{1}{|c|}{$\begin{array}{c}\text { Variabel } \\
\text { Independen }\end{array}$} & $\begin{array}{c}\text { Predictio } \\
\text { ns }\end{array}$ & B & Wald & Sig. & Exp(B) & Explanations \\
\hline $\begin{array}{l}\text { Tax } \\
\begin{array}{l}\text { Minimization } \\
\text { (X1) }\end{array}\end{array}$ & + & 0.176 & 4.350 & 0.037 & 1.193 & H1 Supported \\
\hline $\begin{array}{l}\text { Bonus } \\
\text { Mechanism } \\
\text { (X2) }\end{array}$ & + & 0.492 & 1.209 & 0.272 & 1.635 & H2 Not supported \\
\hline $\begin{array}{l}\text { Foreign } \\
\text { Ownership } \\
\text { (X3) }\end{array}$ & + & 1.359 & 0.549 & 0.459 & 3.892 & H3 Not supported \\
\hline $\begin{array}{l}\text { Exchange } \\
\text { Rate (X4) }\end{array}$ & + & -3.099 & 1.967 & 0.161 & 0.045 & H4 Not supported \\
\hline $\begin{array}{l}\text { Audit } \\
\text { Quality (X5) }\end{array}$ & - & -1.258 & 2.049 & 0.003 & 4.263 & H5 Supported \\
\hline Constant & & -1.276 & 1.237 & 0.266 & 0.279 & \\
\hline
\end{tabular}

Source: Results of data processing with SPSS 22.0 software, 2021

\section{Effects of Tax Minimization on Transfer Pricing}

The first hypothesis which states that tax minimization has a positive effect on transfer pricing decisions is supported. This shows that the greater the amount of tax burden that companies must pay to the state, profit-oriented manufacturing companies are increasingly triggered to do various ways in order to minimize the amount of tax that must be paid by one way to implement transfer pricing. The results of this study are consistent with research by Saraswati et al. (2017:1024) and Tiwa et al. (2017:2673), and Nurjanah et al. (2015: 11) which states that tax minimization has a positive effect on transfer pricing decisions. To reduce the total tax burden, manufacturing companies choose to carry out tax management by conducting transactions with other companies in other countries that are still affiliated. The possibility for companies to practice transfer pricing will increase if a country imposes a high tax rate. Companies that get high profits and are in countries that have high tax rates will shift profits and revenues to countries that are classified as low tax countries. Information asymmetry that occurs between shareholders and management gives management freedom to carry out activities that are not fully known by shareholders. In this case, management utilizes tax loopholes between different countries to practice transfer pricing to reduce the tax burden (Saraswati et al., 2017:1022).

\section{Effect of Bonus Mechanisms on Transfer Pricing}

The second hypothesis which states that the bonus mechanism has a positive effect on transfer pricing decisions is not supported. These results indicate that the bonus mechanism does not encourage the transfer pricing action of manufacturing companies in Indonesia. The results of this study are not in accordance with Hartati et al. (2015: 15) and Nurjanah et al. (2015: 11) which shows that the bonus mechanism has a significant positive effect on transfer pricing. The results of this study are consistent with research by Saraswati et al. (2017:1022), Refgia (2017: 553) and Rosa et al. (2017: 12) and Mispiyanti (2015: 72) which show that the bonus mechanism does not significantly influence transfer pricing. This is likely because the company wants to get a high bonus and the directors dare to do transfer pricing transactions to provide a temporary increase 
in profits for the company, so this is very inappropriate. The results of this study are also in accordance with the study of Wafiroh and Hapsari (2016) which states that if only because of the motive of wanting to get bonus directors dare to do transfer pricing transactions in order to provide temporary profit increases for the company then this is very unethical given there are far greater interests namely maintaining the value of the company in the eyes of the public and the government by presenting financial reports that are reliable and can be used for the purpose of decision making of its users. This result is likely due to the bonus mechanism in this study which is measured based on the profits of the company. In carrying out their duties, the directors tend to want to show good performance to company owners, one of which is trying to report high corporate profits. With high profits, the directors will get an award in the form of a bonus. However, it is possible that the Board of Directors will not only implement ways to maximize company profits by conducting transfer pricing practices.

\section{Effect of Foreign Ownership on Transfer Pricing}

The third hypothesis which states that foreign ownership positively influences the transfer pricing decision is not supported. The results of this study are not in accordance with Refgia (2017: 553) and Kiswanto \& Purwaningsih (2013:12) which show that foreign ownership has a positive effect on transfer pricing. This study is in accordance with research conducted by Tiwa et al. (2017:2673) and Nurjanah et al. (2015:12) which shows that foreign ownership does not affect the transfer pricing decision. The lack of influence of foreign ownership on the transfer pricing practice is likely due to the fact that foreign controlling shareholders prefer the long-term sustainability of the company so that they do not use their position to influence decisions that may harm the long-term company, including transfer pricing decisions that are likely to harm the long-term company.

\section{Effect of Exchange Rate on Transfer Pricing}

The fourth hypothesis which states that the exchange rate has a positive effect on the transfer pricing decision is not supported. The results of this study are not in accordance with the research of Chan et al. (2014:13) which states that multinational companies might try to reduce the risk of foreign exchange rates by moving funds to strong currencies through transfer pricing to maximize overall corporate profits. This result is in accordance with research by Marfuah and Azizah (2014:164) which states that the size of the exchange rates does not affect the company's judgment whether the company will choose to make a transfer pricing decision in the company or not. This result is likely due to the fact that if the company moves funds to a strong currency, the constantly fluctuating currency exchange rate that is possible can cause the number of units of the originating currency needed to change so that it will not allow the exchange rate to be used as an effort. to do transfer pricing. Another possibility is caused by two accounting effects in the exchange rate, namely to include foreign currency transactions and disclosure of gains and / or losses that can affect the company's overall profit. In the sample company's financial statements used, there are many losses on foreign exchange earnings or losses so that exchange rates do not become the main focus of management's tendency to utilize transfer pircing transactions.

\section{Effect of Audit Quality on Transfer Pricing}

The test results of the fifth hypothesis proves that the quality of the audit significant negative effect on the decision of transfer pricing on manufacturing companies listed in Indonesia Stock Exchange in 2017-2019. These results indicate that manufacturing companies audited by the Public Accounting Firm-The Big Four tend not to carry out 
aggressive tax policies. This is because the higher the quality of the audit results of a company, the more transparent the company tends to be in reporting information about taxes so that the practice of transfer pricing in the company will decrease. The results of this study are in accordance with Mayowan \& Karjo (2016:7) which also show that audit quality has a significant negative effect on transfer pricing.

\section{Conclusions and Suggestions}

This study aims to determine the effect of tax minimization, bonus mechanisms, foreign ownership, exchange rates, and audit quality on transfer pricing in manufacturing companies in Indonesia. The results of this study concluded that (1) the tax minimization variable proved to have a significant positive effect on transfer pricing decisions. This indicates that the greater the amount of tax burden that must be paid by the company to the state, the more profit-oriented manufacturing companies are triggered to take various ways in order to minimize the amount of tax to be paid, one of which is by doing transfer pricing, (2) Quality variable audit is proven to have a significant negative effect on transfer pricing. This shows that the companies audited by the Public Accounting FirmThe Big Four tend not to carry out transfer pricing between companies that have a special relationship, and vice versa, (3) The bonus mechanism variables, foreign ownership and the exchange rate do not have a significant positive effect on the company's transfer pricing decision.

\section{Limitations and Suggestions}

This research has limitations that are expected to be fixed by future researchers. This research was conducted at manufacturing companies without regard to the industrial sector. Future studies are expected to develop this research by conducting additional tests, for example conducting a comparative test (different test) of the transfer pricing practice between the manufacturing industry sub-sectors or comparing the transfer pricing practice with the non-manufacturing industry.

\section{References}

Annisa, N.A.; dan Kurniasih, L. 2012. "Pengaruh Corporate Governance Terhadap Tax Avoidance". Jurnal Akuntansi \& Auditing, Vol. 8, No. 2: 95-189.

Chan, C.; Landry, S. P.; and Jalbert, T. 2004. "Effects of Exchange Rates on International Transfer Pricing Decisions". International Business \& Economic Research Journal, Vol 3, No.4: 35-48.

Datar, S.M.; and Rajan, M.V. 2018. Horngren's Cost Accounting: A managerial Emphasis. 11 th ed. England: Pearson.

Dyanty, V.; Sodharta U.; Hilda R.; and Sylvia V. 2011. "Pengaruh Kepemilikan Pengendali Akhir Terhadap Transaksi Pihak Berelasi". Prosiding SNA XV, Banjarmasin, 1-25.

Gusnardi. 2009. "Penetapan Harga Transfer Dalam Kajian Perpajakan". Jurna Pendidikan Ekonomi dan Bisnisl. Vol. 1.No. 1: 36-43.

Hartati, W.; Desmiyawati dan Julita. 2015. "Tax Minimization, Tunneling Incentive dan Mekanisme Bonus terhadap Keputusan Transfer Pricing Seluruh Perusahaan yang Listing di Bursa Efek Indonesia". Prosiding SNA XVIII: 1-18. 
Kiswanto, N.; dan Purwaningsih, A. 2013. "Pengaruh Pajak, Kepemilikan Asing, dan Ukuran Perusahaan terhadap Transfer Pricing pada Perusahaan Manufaktur di BEI Tahun 2010-2014". E-Jurnal UAJY: 1-15.

Lo, W. Y. A.; Raymond, M.K W.; and Micheal F. 2010. "Tax, Financial Reporting, and Tunneling Incentives for Income Shifting: An Empirical Analysis of the Transfer Pricing behavior of Chinese-Listed Companies". Journal of the American Taxation Association. Vol. 32. No. 2:1-26.

Marfuah, \& Azizah, A. P. N. 2014. "Pengaruh Pajak, Tunneling Incentive, dan Exchange Rate pada Keputusan Transfer Pricing Perusahaan". Jurnal Akuntansi Dan Auditing Indonesia. Vol 18, No.2: 156-165.

Mayowan, Y.; dan Karjo, S. 2016. "Pengaruh Pajak, Tunneling Incentive, dan Good Corporate Governance (GCG) terhadap Indikasi Melakukan Transfer Pricing pada Perusahaan Manufaktur yang Terdaftar di Bursa Efek Indonesia (Studi pada Bursa Efek Indonesia yang Berkaitan dengan Perusahaan Asing". Jurnal Perpajakan (JEJAK), Vol.8, No. 1:1-9.

Mispiyanti. 2015. "Pengaruh Pajak, Tunneling Incentive dan Mekanisme Bonus Terhadap Keputusan Transfer Pricing". Jurnal Akuntansi Dan Investasi, Vol 16, No. 1: 62-73.

Nurjanah, I.; Isnawati; dan Sondakh, A.G. 2015. "Faktor Determinan Keputusan Perusahaan Melakukan Transfer Pricing". Prosiding SNA XIX: 1-16.

Refgia, T. 2017. "Pengaruh Pajak, Mekanisme Bonus, Ukuran Perusahaan, Kepemilikan Asing, dan Tunneling Incentive terhadap Transfer Pricing". JOM Fekon, Vol. 4, No.1: 543-555.

Rosa, R.; Andini, R.; dan Raharjo, K. 2017. "Pengaruh Pajak, Tunneling Incentive, Mekanisme Bonus, Debt Convenant, dan Good Corporate Governance (GCG) terhadap transaksi Transfer Pricing (Studi pada Perusahaan Manufaktur yang terdaftar di Bursa Efek Indonesia tahun 2013-2015". Jurnal Unpand, Vol. 3, No.3:114.

Sari, E. V. 2016. "DJP Bongkar Motif 2000 Perusahaan Yang kemplang Pajak". Diakses dari https://www.cnnindonesia.com/ekonomi/20160328115246-78-119992/djpbongkar-motif-2000-perusahaan-yang-kemplang-pajak.

Saraswati, G.A.R.S. dan Sujana, I. K.2017. "Pengaruh Pajak, Mekanisme Bonus, dan Tunneling Incentive Pada Indikasi Melakukan Transfer Pricing". E-Jurnal Akuntansi Universitas Udayana, Vol.19, No.2: 1000-1029.

Setiawan, H. 2016. "Transfer Pricing dan Risikonya terhadap Penerimaan Negara." 1:12. Diakses dari https://www.kemenkeu.go.id/

Suandy, E. 2011. Hukum Pajak. Jakarta: Salemba Empat.

Tiwa, E. M.; Saerang, D. P.; dan Tirayoh, V. Z. 2017. "Pengaruh Pajak dan Kepemilikan Asing Terhadap Penerapan Transfer Pricing pada Perusahaan Manufaktur yang Terdaftar di BEI Tahun 2013-2015". Jurnal EMBA, Vol. 5, No. 2: 2666-2675. 
Wafiroh , N.l; dan Hapsari, N. N. 2016. "Pajak, Tunneling Incentive dan Mekanisme Bonus Pada Keputusan Transfer Pricing". Jurnal Muhabasa: Jurnal Akuntansi, Vol.6, N0. 2: 157-168.

Yuniasih, W. N.; Rasmini, N. K.; dan Wirakusuma, M.G. 2012. "Pengaruh Pajak Dan Tunneling Incentive Pada KeputusanTransfer Pricing Perusahaan Manufaktur Yang Listing Di Bursa Efek Indonesia". Prosiding SNA XV: 1-23. 
